\title{
Saarbrücken 1998
}

\author{
By Ron Holloway
}

Spring 1999 Issue of KINEMA

\section{MAX-OPHÜLS-PRIZE FESTIVAL IN SAARBRÜCKEN}

One of the many fine moments at the 19th Max-Ophüls-Prize competition in Saarbrücken (27 January - 1 February 1998), a festival spotlighting new talent in German-language cinema, was Peter Lichtefeld's Zugvögel ...einmal nach Inari (Passage ... One Way to Inari, Germany). A strikingly photographed (cameraman Frank Griebe) roadmovie, it features Jochim Król as Hannes, a shy beer-truck-driver and railroad-nut whose peculiar hobby is train schedules and knowing the shortest way from place to place. When Hannes enters the "First International Competition for Fastest Timetable Reading," the contest brings him to the town of Inari in the far north of Finland, But not before he finds himself involved in a murder case with a police inspector in hot pursuit. Along the way he meets, and falls in love with Sirpa (Outi Mäenpää), a Finnish miss who gets off the train in Helsinki and thus turns Hannes's own timetable upside down. The diversion also allows for a delightful rendezvous with Kati Outinen and Kari Väänänen, members of the Kaurismäki Brothers' acting company. The film's laconic, scurrilous humor, together with the adept blending of landscape images into the narrative, makes for a rewarding viewing experience.

The prestigious Max-Ophüls-Prize, along with Screenplay Prize of Saarländischer Rundfunk, was awarded to Sandra Nettelbeck's Mammamia (Germany), a familiar drama of family relations but with a twist. Senta Berger, as the wife-mother who hasn't yet gotten a grip on her place in life, brings substance to a challenging role. Nettelbeck will be remembered for her exceptional debut feature film programmed two years ago at Saarbrücken: Unbeständig und kühl (Fickle and Cool, 1995), an insightful tale about young people entwined in complex sexual and emotional relationships.

The Prize of the Saarland Minister President (Oskar Lafontaine, who was present at the closing ceremonies) was awarded to Stefan Ruzowitzky's Die Siebtelbauern (The One-Seventh Farmers, Austria), a baroquepitched Heimat-Western set in the rocky Mühlviertel region between the two world wars. When seven farmhands inherit their deceased master's farm, their determined effort to make a go of it arouses the ire of the local gentry and prompts a bloody showdown. Simon Schwarz, as Lukas, one of the farmhand leaders, was named Best Young Actor by the festival. Ruzowitzky will also be remembered for winning the Jury Grant Prize at the 1997 Saarbrücken festival for Tempo (Austria, 1996), a fast-paced sketch of the life-and-times of a hapless young bike-courier in today's Vienna.

Another double winner was Janek Rieke's Härtetest (Survival Test, Germany), awarded the Interfilm Prize and the Public's Prize. This hilarious comedy about a rocky romance between Jonas (played by writerdirector Rieke), the shy pampered son of a rich merchant-ship owner, and Lena (Lisa Martinek), a spunky environment terrorist on a bicycle, introduces an all-around talent with a light hand for screwball comedy. Editor Brigitte Kirsche, who collaborated with documentarist Eberhard Fechner on his monumental Der Prozess (The Trial, 1983), had a hand in refining Survival Test to one of the best films of the season by a new talent.

The same can be said for Stefan Schneider's Erntezeit (Harvest Time, Germany), the most original film of the festival on several aesthetic counts: intricate Beckettian interplay of time and plot, subtle yet sure handling of actors, rhythmic Sisyphus-like dance-ritual, and elusive visual images reminiscent of Hopper and Wyeth. A film without dialogue or commentary (save for what is heard on the radio), it leaves the viewer with the feeling that these mute, taciturn individuals residing in an old house on an abandoned landscape may never leave the place, no matter how much they ache to do so.

Hans-Erich Viet's Geiselfahrt in's Paradies (Hostage Flight to Paradise, Germany) arrived at Saarbrücken direct from the lab. A wacky tale about a lotto-robbery by an unemployed, lame-brained, shortwave radio nut who dreams of taking the next flight to China, Viet's country bumpkin from the Frisian coast only gets as far as an island in the North Sea. But that's more than enough -- for, as in the postwar British comedies at the Ealing Studios, Hostage Flight to Paradise pokes irreverent fun at the pompous and conceited in a bizarre tale loaded with humorous gags and unexpected twists. Hubertus Hartmann as the would-be robber, 
accompanied by Gesa Badenhorst and Anna Luhn as the helpful mother-daughter hostages, make room along the way for walk-on cameos by familiar personalities: for instance, Horst Frank, a well-known TV police-inspector, plays the helpful owner-manager of "Sterna Paradisa," a wayside inn in the sand-dunes.

Andreas Wunderlich's debut feature Fünf-Uhr-Schatten (Five O'Clock Shadow, Germany) appears on the surface to be a Bergman-like Scenes from a Marriage run-through, but this highly stylized roadmovie, more a journey into the self, features exceptional acting performances by Susanne Leutenegger and Thierry van Werveke. Abrupt turns and twists in the story both surprise and bewitch, for this is a strange couple on their lonely odyssey along the Rhine that might as well lead to a crossing of the River Styx.

Bence Gyöngyössy's Romani Kris -- Zigeunergesetz (Gypsy Law, Germany-Hungary), awarded the Prix de Montréal for Best Debut Film at the 1997 Montreal World Film Festival, draws upon Shakespeare's King Lear to chronicle the tragic fall and death of a Gypsy patriarch who strips his beloved youngest daughter of her inheritance and then searches for her in the bars of Budapest and along country byways to seek her forgiveness. Beautifully photographed (cameraman Tomás Sas), it's the scenes in the Gypsy camps that confirm the talent of the son of Imre Gyöngyössy, who returned to the scene of his father's earlier success, Legend about the Death and Resurrection of Two Young Men (Hungary, 1972), to integrate in Romani Kris the same surrealist motifs drawn from myths, symbols, and folklore.

Oskar Roehler's Silvester Countdown (Germany), a debut feature awarded a share of the Hypo-Bank Prize at the 1997 Filmfest München, also drew upon Shakespeare's Romeo and Juliet to sketch a flamboyant, no-holds-barred relationship between a young couple in Berlin of the 1990s. Although neither is ripe for an on-going relationship, and their love appears to be on the rocks from the very beginning, the strong performances of Rolf Peter Kahl and Marie Zielcke (named Best Young Actress) as the couple who view life as a nonstop New Year's Eve party strikes a nerve by raising the unsettling question: where does the young generation go from here?

The same quest for moral answers can be felt in Christian Petzold's Die Beischlafdiebin (The Bed Companion Thief, Germany), about an attractive middle-aged woman who has spent her adult lifetime drugging male tourists in luxury hotels abroad in order to finance her younger sister's education, only to find out that the sibling has wasted the money. In Edward Berger's Gomez -- Kopf oder Zahl (Gomez -- Heads or Tails, Germany), the disheartening tale of a 16-year-old lad who drifts into crime, a search is made for answers to spreading teenaged criminality. And in his atypical detective story, Die Spur (The Trace, Germany), Peter Ott narrates his tale of illegal laundering of mafia-money from the aesthetic perspective of computer technology and the Internet.

The competition with its 19 entries was almost too much for a five-day festival, yet room has always been made at Saarbrücken for newcomers and new generation filmmakers. And thanks to the selecting finesse of Ewald Blum, the riches of short film production at the various film schools were again clearly visible. Sebastian Peterson's Fake! (Germany), awarded Best Short Film, spoofs all of cinema's genres in a roll-with-thepunches 12-minute reel-off. Other shorts to make a note of were: Benjamin Herrmann's Der Grosse Lacher (The Big Laugh), Anna Faroqhi's Silber und Gold, Menga Huonder-Jenny's Frau im Schatten (Woman in Shadow), Jophi Ries's Marco at Work, Maria von Heland's Chainsmoker, and Gordian Maugg's Hans Warns 1914-1921. Also, Manfred Kirchheimer, film professor at Manhattan's School of Visual Arts, returned to Saarbrücken with another representative collection of "New York Short Films" made by his students.

Cineastes enthusiastically applauded the presentation of a restored print of Max Ophüls's Caught (USA, 1948), the director's American masterpiece about an eccentric millionaire modeled after the personality of Howard Hughes. Yet another highlight was the festival presentation to piano accompaniment of a restored print of Karl Grune's silent spectacle Waterloo (1929), his ambitious response to Abel Gance's Napoleon (France, 1926). Appropriately, festival director Christel Drawer opened with Hermine Huntgeburth's Das Trio (Germany), starring Götz George in the role of a gay pickpocket and slight-of-hand thief -- typical for Saarbrücken: a veteran actor directed by a talented young woman filmmaker. 


\section{Author Information}

Ron HOLLOWAY (1933-2009) was an American critic, film historian, filmmaker and correspondent who adopted Europe as his home in the early fifties and spent much of his life in Berlin. He was an expert on the study of German cinema and against all odds produced, with his wife Dorothea, the journal German Film, keeping us up-to-date with the work of directors, producers and writers and the showing of German films around the world.

In 2007, Ron Holloway and his wife were awarded the Berlinale Camera Award. Ron also received the Bundesverdienstkreuz (German Cross of Merit), Polish Rings, Cannes Gold Medaille, the American Cinema Foundation Award, the Diploma for Support of Russian Cinema and an honorary award from the German Film Critics' Association.

Ron was also a valued contributor to Kinema for the past fifteen years. 